year. The Soviet authorities, on the other hand, will have no such obligation.

Andrei Sakharov's explanation of his despair is, as always, moving but, on this occasion, strangely unreal. His sense of responsibility derives from having urged his son Alyosha to emigrate when a brief opportunity appeared in 1978, leaving his fiancée behind. (They were later married by proxy in Montana.) But the Soviet authorities are habitually so slow to grant exit visas to citizens wishing to join foreign spouses as to support the belief that they are not willing to do so. The Sakharovs know this, and must also suspect that the sacrifice on which they have embarked may prove fruitless: if they should die, Liza Alexeyeva will be even less well-placed than at present. The Sakharovs' courage is admirable and beyond dispute. Is it possible that on this occasion their isolation has led them to misjudge the future?

Andrei Sakharov's explanation lends some support to that unhappy guess. He complains that appeals for help with his immediate problem addressed to four members of the Soviet Academy have come to nothing, and that one of those asked Academician Ya. Z'eldovich - had flatly refused to help on the grounds of the "shakiness of his own position". Sakharov goes on to accuse Z'eldovich of abandoning responsibility. It is, however, well-known in the West that Z'eldovich, a distinguished theoretical physicist turned cosmologist, is among that large company of Soviet scientists unable to accept invitations to conferences abroad. Sakharov's own protest against illiberality has hitherto been entirely admirable. In the loneliness of his exile, it is natural that he should be looking to others for help. What they do, and how they do it, is nevertheless for them to decide. That the Sakharovs themselves have fallen back on the hunger strike is especially distressing, not merely because of the risks involved but because the hunger strike is essentially an irrational form of protest. Governments may yield on particular points, but are unlikely to recast their policies as a result. More often, they dig in their heels, declining to give in to emotional blackmail.

\section{Academic cat and mouse}

Can Sir Keith Joseph, the least successful minister in the British Government, be trusted with the universities?

The proposition that higher education is too important to be left to educationists would be widely accepted. But can the future of British higher education safely be entrusted to Sir Keith

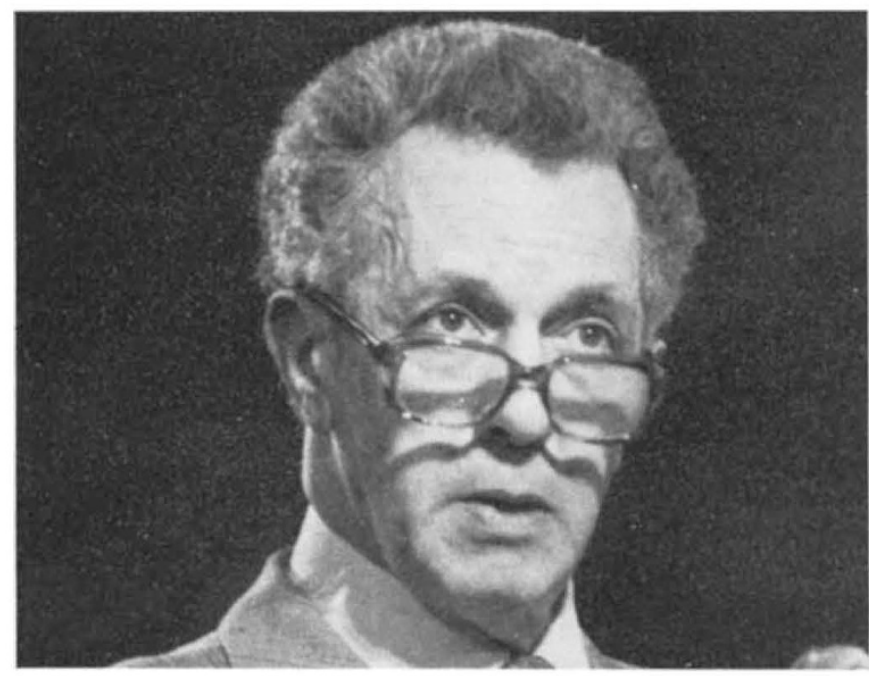

Joseph, the present Secretary of State for Education and Science? In a debate last week in the House of Commons, Sir Keith uttered this perplexing statement:

Those who maintain that it would be educationally less harmful but still productive of the same savings to go slower have not made out their case. I concede that logically such a case could be made, but I do not believe that it has been made.
If one is made 1 shall consider it.

If words, even as interpreted by Hansard shorthand writers, mean anything, he was saying that British universities have not yet found the forms of words with which to defend themselves against the folly of his government's decision that the university budget should be reduced by 15 per cent in three years At the same time, however, Sir Keith implied that if only academics were as smart as he is, they would get their act together and persuade him, as he secretly knows they could, that their case for a less draconian contraction makes economic as well as academic sense. And secure as he is in the knowledge that no British academic will pass that stringent test, he will let the system founder.

Sir Keith has a curious reputation, more that of an intellectual than of a politician. His spell as Secretary of State for Industry is memorable chiefly for his advocacy of the importance of market forces and for his contradictory willingness to make out a cheque for whichever nationalized industry was then in trouble. Last week, he rightly challenged his critics to explain how an openended commitment by British governments to meet the cost of educating all qualified entrants could be reconciled with the limited capacity of taxpayers to meet the cost. The answer (which follows) is not arithmetical.

Sir Keith was right last week implicitly to say that no British government could permanently agree that all "qualified" students should be educated free, in the disciplines of their choice, at the taxpayers' expense. He should also have done the decent thing and said that Robbins, as a principle, is dead. What bothers the government about the open-endedness of its inherited commitment, however, is not so much the cost of operating the universities as that of paying maintenance grants to students. Sir Keith's officials are already negotiating with the National Union of Students on the students' demand that their maintenance grants should be increased by nearly 18 per cent. The officials will have at least one hand tied behind their backs by the legislation that compels each local authority to pay maintenance grants to students whenever they are awarded places at institutions of higher education. The profligacy of this legislation is, outside the United Kingdom, beyond belief. Not merely does it constitute Sir Keith's chief problem but it is the albatross hung around the neck of the university system. Replacing the present system of mandatory student grants, limitless in cost, with a system of scholarships awarded to deserving people would help not merely to solve the universities' problems but would get Sir Keith Joseph off the hook on which he has quickly (but characteristically) impaled himself. Unhappily, neither the universities nor the minister supposedly responsible for their welfare have the stomach for such a fight.

\section{Monument for a giant}

\section{Sir Hans Krebs died this weekend in Oxford.}

It is quite true that in the 1930s, Nature declined to publish Sir Hans Krebs's article on what most people have since called the Krebs cycle. The explanation given was that the article should be placed in a more specialized journal. Krebs himself cherished the rejection slip but modestly and confusingly always referred to the biochemical cycle he first described by its original name, the "citric acid"' cycle (see Nature 291, 381; 1981).

Krebs, a refugee from Nazi Germany, carried with him Warburg's way of regarding the biochemical problems of metabolism and, perhaps more important, Warburg's techniques. But only Krebs's flair can account for his unmasking of the intricacies of the most rudimentary of the metabolic processes in animal tissues - the oxidation of sugars to form ATP - with the techniques of half a century ago. Inevitably, that single piece of work will be his chief monument. Another is in danger of being overlooked. Krebs, naturally a magnet for students, modestly bent his energies to teach them all he knew. At one stage, more than a dozen British chairs of biochemistry were occupied by his students. He was a giant eager that his shoulders should be used by younger people. 